\title{
PERSPEKTIF SPIRITUALISME DALAM PEMBELAJARAN SEJARAH
}

Sardiman AM.

Program Studi Pendidikan Sejarah, Fakultas Ilmu Sosial

Universitas Negeri Yogyakarta

\begin{abstract}
Abstrak
Banyak materi pembelajaran yang dapat dimanfaatkan untuk membangun karakter bangsa, dengan melalui penanaman dan transformasi nilai-nilai keimanan dan ketakwaan, akhlak mulia dan nilai-nilai luhur ke-Indonesia-an seperti nilai-nilai religiositas, kemanusiaan dan keadilan, sosialisme, nasionalisme, patriotisme, demokrasi, toleransi, kearifan, keteladanan. Tentu hal ini sangat menuntut keberanian dan kreativitas guru. Dan sebagai bagian dari upaya pengembangan profesionalismenya, guru perlu merubah pembelajaran sejarah yang kognitif menjadi pembelajaran yang lebih bermakna, kontekstual, dan menyentuh aspekaspek afektif atau kecerdasan emosional, serta kecerdasan spiritual. Pembelajaran sejarah yang bersifat kognitif hanya akan melahirkan kepuasan dengan durasi sesaat, sebaliknya pembelajaran sejarah yang mampu melatih kecerdasan emosional dan spiritual, akan melahirkan kesadaran sejarah yang sejati. Inilah modal penting untuk mewujudkan bangsa yang berkarakter, bangsa berkepribadian.
\end{abstract}

Kata Kunci: Spiritualisme, Pembelajaran, Sejarah 


\section{PENDAHULUAN}

Mengapa seseorang menjadi koruptor?, mengapa seseorang menjadi perusak lingkungan hutan di Indonesia? Salah satu jawabnya, karena mereka itu tidak memiliki kesadaran sejarah. Mereka lupa dan tidak menyadari bahwa bumi dan tanah air ini ditegakkan dengan darah dan air mata, dengan jiwa, raga dan harta. Mereka tidak sadar bahwa bumi, alam dan seisinya ini diciptakan oleh Tuhan Allah SWT., untuk kemaslahatan orang banyak, dititipkan untuk anak cucu kita. Harus diakui bahwa kesadaran sejarah di kalangan masyarakat kita mengalami degradasi. Kita sudah lupa pada dimensi kelampauan kita. Mengapa? Salah satu sebabnya pembelajaran sejarah kita bersifat kognitif, cenderung hafalan dan kurang bermakna dalam kehidupan keseharian, di samping dinamika kehidupan masyarakat yang cenderung konsumtif-materialistik. Secara tidak terasa sekularisasi sedang berkecamuk di lingkungan dan kehidupan kita. Nilai dan ruh spiritualisme dari setiap realitas sejarah yang tergambar dalam ayat-ayat Tuhan baik yang qauniyah maupun qauliyah, tidak lagi terbaca oleh masyarakat dan warga bangsa ini.
Pembelajaran sejarah sebenarnya tidak sekedar menjawab pertanyaan what to teach, tetapi bagaimana proses pembelajaran itu dilangsungkan agar dapat menangkap dan membangun nilai serta mentransformasikan pesan di balik realitas sejarah itu kepada peserta didik. Proses pembelajaran ini tidak sekedar peserta didik menguasai materi ajar, tetapi diharapkan dapat membantu pematangan kepribadian peserta didik sehingga mampu merespon dan beradaptasi dengan perkembangan sosio kebangsaan yang semakin kompleks serta tuntutan global yang semakin "ngrangsek".

Kehidupan bangsa Indonesia dewasa ini ternyata belum seperti yang dicita-citakan. Peristiwa politik tahun 1998 yang telah mengakhiri kekuasaan Orde Baru dengan berbagai euforianya ternyata menyisakan luka mendalam di berbagai aspek kehidupan bermasyarakat, berbangsa, dan bernegara. Berbagai bentuk pelanggaran masih terus terjadi. Tindakan kekerasan dan pelanggaran HAM, perilaku amoral dan runtuhnya budi pekerti luhur, anarkhisme dan ketidaksabaran, ketidakjujuran dan budaya nerabas, rentannya kemandirian dan jati diri bangsa, terus menghiasai kehidupan 
bangsa kita. Semangat kebangsaan kita turun tajam dan di mata masyarakat internasional sepertinya kita telah kehilangan karakter sebagai bangsa ramah, arif dan religius yang selama beratus-ratus tahun bahkan berabadabad kita bangun. Pada kondisi yang seperti ini nampaknya pendidikan karakter kebangsaan melalui pembelajaran sejarah dengan perspektif spiritualisme, menjadi amat strategis. Pada tulisan singkat ini mencoba ingin sharing pemahaman dan berbagi rasa tentang tema "Perspektif Spiritualisme dalam Pembelajaran Sejarah”.

\section{Menyoal Tujuan Pembelajaran}

Muara tujuan pembelajaran sejarah adalah berkembangnya kesadaran sejarah di kalangan peserta didik. Pembelajaran sejarah adalah suatu proses untuk membantu pengembangan potensi dan kepribadian peserta didik melalui pesan-pesan sejarah agar menjadi warga bangsa yang arif dan bermartabat. Sejarah dalam hal ini merupakan totalitas dari aktivitas manusia di masa lampau (Walsh, 1967: 16), dan sifatnya dinamis. Maksudnya, bahwa masa lampau itu bukan sesuatu final, tetapi bersifat terbuka dan terus berkesinambungan dengan masa kini dan yang akan datang. Karena itu sejarah dapat diartikan sebagai ilmu yang meneliti dan mengkaji secara sistematis dari keseluruhan perkembangan masyarakat dan kemanusiaan di masa lampau dengan segala aspek kejadiannya, untuk kemudian dapat memberikan penilaian sebagai pedoman penentuan keadaan sekarang, serta cermin untuk masa yang akan datang.

Lebih jauh pengertian sejarah juga berkait dengan persoalan kemanusiaan dan sebuah teater di mana manusia menjadi pemain watak, berdasarkan pengetahuan, pengalaman, dan keteladanan yang sudah ada. Sejarah akan mendidik manusia untuk memahami "sangkan paran " dan keberadaan dirinya (Soedjatmoko, 1986:6), sehingga dapat memperkuat identitas diri dan identitas nasional, atau identitas sebagai suatu bangsa. Dalam kaitan ini maka pembelajaran sejarah berfungsi untuk menumbuhkan kesadaran sejarah. Kesadaran sejarah adalah suatu orientasi intelektual, dan suatu sikap jiwa untuk memahami keberadaan dirinya sebagai manusia, anggota masyarakat, dan sebagai suatu bangsa (Soedjatmoko, 1986: 7). Taufik Abdullah (1974: 10) ) menegaskan 
bahwa kesadaran sejarah tidak lain adalah kesadaran diri. Kesadaran diri dapat dimaknai sadar akan keberadaan dirinya sebagai individu, sebagai makhluk sosial termasuk sadar sebagai bangsa dan sadar sebagai makhluk ciptaan Tuhan (Sardiman A.M., 2005: 61). Dalam konteks ini pada diri manusia sebenarnya ada dua dimensi, yakni dimensi "kehambaan dan kekhalifahan".

Dengan pemahaman tersebut, pembelajaran sejarah dituntut paling tidak dapat mengaktualisasikan dua hal yakni: (1) pendidikan dan pembelajaran intelektual, (2) pendidikan dan pembelajaran moral bangsa, civil society yang demokratis dan bertanggungjawab kepada masa depan bangsa (Djoko Suryo, 1991: 11). Hal yang pertama menuntut pembelajaran sejarah tidak hanya menyajikan pengetahuan faktual, namun dituntut untuk memberikan latihan berfikir kritis, mampu menarik kesimpulan, memahami makna dari suatu peristiwa sejarah menurut kaidah dan norma keilmuan. Pertanyaan-pertanyaan mengenai mengapa dan bagaimana, penting untuk dikembangkan dalam proses pembelajaran sejarah. Sementara itu hal yang kedua menunjuk pada pembelajaran sejarah yang berorientasi pada pendidikan kemanusiaan yang memperhatikan nilai-nilai luhur, norma-norma, religiositas, dan aspek kemanusiaan lainnya.

Dengan mengembangkan dua hal : pendidikan intelektual dan pendidikan moral atau pendidikan kemanusiaan, maka arah pembelajaran sejarah diharapkan dapat mencapai tujuan yang menopang tercapainya tujuan pendidikan nasional. Pembelajaran sejarah akan dapat melandasi pendidikan kecerdasan intelektual, sekaligus ikut mendasari pendidikan yang berorientasi pada kecerdasan emosional bahkan kecerdasan spiritual dalam rangka meningkatkan martabat manusia Indonesia. Dalam pelaksanaan di sekolah, tujuan pembelajaran sejarah tersebut terkait dengan adanya tujuan yang dikenal dengan istilah instructional effects dan tujuan yang "mengikuti" atau tujuan lebih lanjut yang disebut nurturant effects (uraian selengkapnya lih.dalam Sardiman AM.,2005: 26).

Mencermati rumusan tersebut, nampak jelas bahwa di samping aspek kognitif, dimensi afektif menempati 
porsi yang cukup penting dalam tujuan pembelajaran sejarah. Namun dalam kenyataannya timbul kritik bahwa pendidikan kita cenderung intelektualistik-kognitif. Apabila kecenderungan ini "keterusan" secara kultural dapat melahirkan kecenderungan baru, yakni adanya sekularisasi. Kalau itu terjadi maka orang akan lebih banyak berpikir sekarang bukan esok, dan mengambil paradigma "memiliki" bukan "menjadi" (lih. Erich Fromm, 1987). Hal ini mulai menjadi kenyataan. Masyarakat bahkan mungkin juga para pimpinan kita bangga, karena anak Indonesia memenangkan olimpiade matematika, atau kimia. Kita bangga bahwa anakanak/peserta didik kita semua lulus ujian nasional (yang hanya diwakili oleh beberapa mata pelajaran). Para orang tua juga akan lebih senang kalau nilai matematika anaknya 10 , sekalipun nilai agamanya kurang. Akibatnya, banyak masyarakat yang kurang memperhatikan bahwa pendidikan semestinya tidak hanya meningkatkan kecerdasan intelektual tetapi yang sangat penting bagaimana membangun kepribadian peserta didik dan generasi muda yang bertaqwa, berakhlak mulia, memiliki kemadirian dan kebanggaan nasional.

Begitu juga dalam pembelajaran sejarah masih cukup memprihatinkan. Pembelajaran sejarah lebih banyak hafalan dan bersifat kognitif. Akibatnya pembelajaran sejarah tidak mampu menjangkau kepada aspek-aspek moralitas, menyangkut kecerdasan emosional dan spiritual, pada hal sejarah sendiri sebuah moralitas, tegas Wang Gungwu. Pembelajaran sejarah kita masih jarang yang mampu memasuki wilayah ranah afektif, seperti sikap arif, menumbuhkan semangat kebangsaan, bangga terhadap bangsa dan negerinya, apalagi sampai memahami hakikat dirinya sebagai manifestasi kesadaran sejarah yang paling tinggi. Pada hal nilai dan aspekaspek itulah yang menjadi esensi dari tujuan pembelajaran sejarah. Oleh karena itu, perlu upaya-upaya bagaimana mewujudkan tujuan tersebut.

\section{Membangun Spiritualisme}

Membangun kesadaran sejarah pada diri setiap peserta didik pada hakikatnya membangun karakter anak bangsa. Bagaimana mengembangkan pembelajaran sejarah agar dapat membantu pembangunan karakter anak 
bangsa ini. Salah satu caranya antara lain dengan mengembangkan pembelajaran dengan perspektif spiritualisme. Dengan perspektif ini diharapkan pembelajaran sejarah akan senantiasa menjadi instrumen penting dalam upaya membangun karakter bangsa yang ramah, arif, empati dan religius atau insan yang beriman, cerdas dan berakhlak mulia sesuai nilai-nilai ke-Indonesia-an.

Untuk membangun karakter bangsa yang demikian itu, sejumlah nilai yang perlu dikembangkan dan ditanamkan kepada peserta didik agar dapat dihayati dan diaplikasikan antara lain nilai: keimanan dan ketaqwaan; keadilan dan kesetaraan; nasionalisme dan patriotisme (lih. Kabul Budiyono, 2007); kemandirian dan dan jati diri bangsa; demokrasi dan tanggung jawab; kearifan, toleransi dan menghormati sesama; di samping nilainilai kejujuran, kedisiplinan, kepedulian, serta keteladanan. Beberapa nilai ini sangat relevan dengan arah dan tujuan pembelajaran sejarah. Nilai-nilai itu dapat digali dan dikembangkan melalui pembelajaran sejarah. Dalam hal ini memang sangat diperlukan adanya kreativitas dari para guru sejarah. Para guru sejarah harus menggali dan mampu mentransformasikan nilai-nilai tersebut kepada peserta didik.

Di dalam pelajaran sejarah banyak pokok bahasan atau topik-topik yang mengandung nilai-nilai kesejarahan tersebut. Misalnya ketika sedang membahas periode pra aksara, guru dapat membahas sejarah penciptaan manusia, termasuk mencari siapa manusia pertama, apa beda Adam sebagai khalifah di muka bumi dengan spesies megantropus ataupun pitekantropus. Pada waktu membahas periode Hindu-Budha dan Islam, guru dapat banyak menjelaskan tentang nilainilai ketaqwaan, keberagaman, toleransi dan saling menghargai, nilai-nilai keharmonisan, serta melalui karyakarya budayanya dapat dijadikan instrumen untuk menumbuhkan kebanggaan dan jati diri bangsa. Saat mengkaji materi ajar pada pereiode penjajahan, sangat tepat untuk mengaktualisasikan kembali nilai-nilai jati diri dan hak-hak individu atau hakhak asasi manusia, nilai-nilai kemanusiaan, bahkan secara dikotomis dapat diaktualisasikan nilai-nilai kemerdekaan. 
"Kemerekaan ialah hak segala bangsa, oleh karena itu penjajahan di atas dunia harus dihapuskan karena tidak sesuai dengan perikemanusiaan dan perikeadilan". Satu kalimat dari Pembukaan UUD 1945 ini secara kreatif dapat dibahas satu atau dua kali pertemuan. Para peserta didik diajak untuk memahami dan menghayati nilainilai kemerdekaan diri, nilai-nilai perikemanusiaan dan nilai keadilan untuk kemudian menjadi bagian dari sikap dan perilakunya. Dalam hal ini guru dituntut untuk mampu menjelaskan dan meyakinkan kepada peserta didik agar menyadarai bahwa tindakan kaum penjajah di bumi Nusantara sangat bertentangan dengan nilai-nilai kemanusiaan dan nilai-nilai keadilan sebagai hak-hak asasi manusia. Hakhak individu yang paling asasi dirampas. Tidak ada kebebasan berserikat, tidak ada kebebasan mengeluarkan pendapat dan memeluk agama secara utuh. Padahal Tuhan menciptakan setiap bangsa, setiap manusia anggota masyarakat dalam keadaan sama, kecuali karena kadar keimanannnya. Manusia diciptakan Tuhan sebagai makhluk yang paling sempurna dengan kedudukan mulia yakni sebagai khalifah (pemimpin) di muka bumi yang bertugas membangun dunia demi kemaslahatan semua orang. Jadi penjajahan sangat jelas bertentangan dengan fitrah dan ciptaan Tuhan. Membahas topik-topik pada periode penjajahan ini, peserta didik juga dapat diajak untuk menghayati dan menumbukan sikap patriotisme, sikap dan tindakan anti penjajahan. Harus diyakinkan kepada peserta didik bahwa tindak penajajahan itu adalah perilaku dholim karena menyengsarakan rakyat banyak. Dalam konteks ini dapat diaktualisasikan konsep jihad, "dan barang siapa berjihad di jalan Tuhan, surga adalah pahalanya."

Pembahasan topik-topik yang berkenaan dengan periode pergerakan nasional, guru perlu menekankan nilainilai nasionalisme, persatuan dan kesatuan di antara pluralisme atau keanekaragaman, toleransi dan saling menghargai. Bangsa Indonesia terdiri dari berbagai suku bangsa dan golongan. Tuhan telah menciptakan ini semua sebagai kekayaan dan kekuatan bangsa. Tuhan telah mengajarkan kepada kita bahwa diciptakan-Nya manusia bersuku-suku dan golongangolongan agar kita saling mengenal dan menjalin tali silaturakhim. Kalau sudah demikian maka dengan didorongkan 
oleh keinginan luhur yakni cita-cita ingin merdeka, maka terwujudlah persatuan dan kebersamaan. Usaha untuk mewujudkan persatuan ini berhasil dengan diikrarkannya Sumpah Pemuda yang menyatakan satu tanah air, satu bangsa: Indonesia, dan menjunjung bahasa persatuan yakni Bahasa Indonesia. Sumpah Pemuda menjadi simbol kebersamaan dalam keanekaragaman dan sekaligus memberikan semangat untuk menggalang persatuan demi terwujudnya cita-cita kemerdekaan. Sumpah Pemuda adalah manifesto politik dan ujud nyata dari silaturakhim nasional., "Barang siapa yang mau menghidup-hidupkan silaturakhim maka akan dipanjangkan usianya dan diluaskan rezekinya." Inilah konsep nasionalisme yang dibimbing oleh nilainilai moral, nilai-nilai keagaaman yang oleh Toynbee dikatakan sebagai nasionalisme yang dibimbing oleh nilainilai universal agama-agama atas (higher religions) (lih. A. Syafii Maarif, 1989). Nasionalisme yang tidak dibimbing oleh nilai-nilai moral keagamaan, dapat terjebak pada dua kecenderungan. Pertama, nasionalisme yang sekuler, ekstrim berlebihan yang dapat melahirkan chauvinisme. Bentuk nasionalisme inilah yang dikritik oleh Toynbee, karena telah menyebabkan berkobarnya PD II yang menghancukan peradaban manusia. Kedua, nasionalisme yang lemah sehingga menjadikan pendukungnya tidak memiliki kebanggaan nasional dan jati diri bangsa. Dalam konteks ini guru secara kreatif dapat membahas materi ini, misalnya dengan topik "Telaah Teks Sumpah Pemuda"seperti telah diterangkan di atas.

Selanjutnya untuk membahas topiktopik yang terkait dengan materi ajar pada periode kemerdekaan, guru dapat mengaktualisasikan dan menanamkan nilai-nilai esensial yang relevan kepada para peserta didik, seperti nilai-nilai kemedekaan, kemandirian dan kebebasan yang bertanggung jawab, nilai demokrasi, patriotisme, masalah kepemimpinan dan keteladanan. Agar lebih menumbuhkan kesadaran dan merangsang emosi peserta didik, guru sebagai fasilitator dan motivator dapat membelajarkan peserta didik untuk menelaah teks dan simbol-simbol kebangsaan. Misalnya mendiskusikan tentang teks Pembukaan UUD 1945 alinea 3, “ Atas berkat rahmat Allah Yang Maha Kuasa dan dengan didorongkan oleh keinginan luhur, 
supaya berkehidupan kebangsaan yang bebas, maka rakyat Indonesa menyatakan dengan ini, kemerdekaannya", mendiskusikan makna Sang Saka Merah Putih, mengkaji baris-baris pada Lagu "Indonesia Raya". Kemudian juga bisa membahas biografi beberapa tokoh seperti Bung Karno, Bung Hatta, Sudirman, untuk mendapatkan nilainilai kepemimpinan dan keteladanan.

Di samping telaah tersebut, yang menarik para peserta didik juga dilatih untuk menyampaikan orasi seputar makna kemerdekaan. Contoh kata atau kalimat-kalimat yang penting untuk diorasikan misalnya: Kemerdekaan adalah hak segala bangsa. Kemerdekaan fitrah dan hak asasi manusia sebagai ciptaan Tuhan. Karena itu wajar kalau bangsa Indonesia berusaha dengan segala daya, dengan penuh pengorbanan baik jiwa, raga maupun harta. Dengan semboyan "merdeka atau mati" dan disertai dengan semangat jihad, bangsa Indonesia akan berjuang sampai titik darah penghabisan untuk sebuah kemerdekaan. Hal ini menunjukkan bahwa kemerdekaan Indonesia merupakan hal yang sangat asasi dan tahapan sangat penting bagi eksistensi suatu bangsa.
Misalnya kita akan menanamkan nilai demokrasi. Di dalam upaya mengisi kemerdekaan itu setiap komponen bangsa ingin mewujudkan kehidupan yang lebih baik, kehidupan yang lebih demokratis di segala bidang, sesuai dengan amanat pembukaan UUD 1945. Upaya untuk menciptakan suatu kehidupan yang demokratis telah dirintis sejak Indonesia baru merdeka oleh para pemimpin bangsa seperti Sjahrir, Mohammad Hatta, Sukarno, sampai kemudian dibuka lembaran demokrasi liberal dengan pemilunya yang cukup demokratis, dewasa, dan jurdil. Perjuangan demokrasi ini terus bergulir dengan persepsi para pemimpin seperti Presiden Sukarno di zaman Orde Lama dengan Demokrasi Terpimpinnya, Presiden Suharto dengan Demokrasi Pancasilanya, bahkan sampai era reformasi bercita-cita mewujudkan masyarakat Indonesia Baru, masyarakat madani, yakni masyarakat demokratis dengan hak-hak sipil yang kuat.

Demokrasi dapat diartikan pemerintahan dari, oleh, dan untuk rakyat. Artinya kekuasaan tertinggi berada di tangan rakyat, baik itu dilaksanakan secara langsung maupun melalui perwakilan. Implikasi dari konsep ini maka bila dilihat dari aspek 
kepemimpinan yang demokratis, maka seorang pemimpin yang berkuasa di dalam pemerintahan pada hakekatnya karena atas nama rakyat, karena ia mendapatkan amanat dari rakyat. Sebagai konsekuensinya maka pemimpin harus mengutamakan kepentingan rakyat, melindungi dan menyejahterakan rakyat bukan mengutamakan kepentingan pribadi, keluarga, dan kroni-kroninya.

$$
\text { Kepemimpinan }
$$

yang

demokratis dan bertanggungjawab banyak ditemukan atau dicontohkan dalam pelajaran sejarah umat manusia. Misalnya kepemimpinan Nabi Muhammad SAW dan Khulafa-ur Rasyiddin, di samping tokoh-tokoh yang lain. Nabi Muhammad sendiri mengajarkan bahwa bagi para pemimpin yang meninggal dalam keadaaan menipu rakyat, tidak mengutamakan kesejahteraan rakyat, maka ia haram mencium bau surga, apalagi memasukinya. Inilah salah satu model kepemimpinan dunia yang mengembangkan kepemimpinan demokratis-moralis, kepemimpinan yang amanah, yang sangat penting untuk diajarkan kepada para peserta didik melalui pelajaran sejarah.

\section{PENUTUP}

Demikian beberapa ilustrasi bagaimana mengembangkan materi dan melaksanakan pembelajaran sejarah dengan perspektif spiritualisme. Banyak materi pembelajaran yang dapat dimanfaatkan untuk membangun karakter bangsa, dengan melalui penanaman dan transformasi nilai-nilai keimanan dan ketakwaan, akhlak mulia dan nilai-nilai luhur ke-Indonesia-an seperti nilai-nilai religiositas, kemanusiaan dan keadilan, sosialisme, nasionalisme, patriotisme, demokrasi, toleransi, kearifan, keteladanan. Tentu hal ini sangat menuntut keberanian dan kreativitas guru. Dan sebagai bagian dari upaya pengembangan profesionalismenya, guru perlu merubah pembelajaran sejarah yang kognitif menjadi pembelajaran yang lebih bermakna, kontekstual, dan menyentuh aspek-aspek afektif atau kecerdasan emosional, serta kecerdasan spiritual. Pembelajaran sejarah yang bersifat kognitif hanya akan melahirkan kepuasan dengan durasi sesaat, sebaliknya pembelajaran sejarah yang mampu melatih kecerdasan emosional dan spiritual, akan melahirkan kesadaran sejarah yang sejati. Inilah modal penting untuk mewujudkan 
bangsa yang berkarakter, bangsa berkepribadian.

\section{DAFTAR PUSTAKA}

Ahmad Syafii Maarif, (1989). "Menggugat Toynbee", dalam Eksponen, edisi 5 Maret 1989. Juga lihat Ahmad Syafii Maarif (1985), Al Qur'an : Realitas Sosial dan Limbo Sejarah (Sebuah Refleksi), Bandung: Pustaka.
Djoko Suryo(1996). "Pengembangan Kajian Sejarah dalam Kurikulum SLTA" Makalah, disampaikan pada acara seminar dalam rangka Dies Natalis IKIP Semarang, 13 Maret 1991.

Erich Fromm, (1976). Memiliki dan Menjadi - Tentang Dua Modus Eksistensi (alih bahasa F. Soesilohardo), Jakarta: LP3ES.

Kabul Budiyono, (2007). Nilai-nilai Kepribadian dan Kejuangan 